\title{
ATPase-based implementation of enforced ATP wasting in Saccharomyces cerevisiae for improved ethanol production
}

\author{
Ahmed Zahoor, Katrin Messerschmidt (10, Simon Boecker[1] and Steffen Klamt ${ }^{*}$ (1)
}

\begin{abstract}
Background: Enforced ATP wasting has been recognized as a promising metabolic engineering strategy to enhance the microbial production of metabolites that are coupled to ATP generation. It also appears to be a suitable approach to improve production of ethanol by Saccharomyces cerevisiae. In the present study, we constructed different $S$. cerevisiae strains with heterologous expression of genes of the ATP-hydrolyzing $F_{1}$-part of the ATPase enzyme to induce enforced ATP wasting and quantify the resulting effect on biomass and ethanol formation.

Results: In contrast to genomic integration, we found that episomal expression of the aßY subunits of the $F_{1}$-ATPase genes of Escherichia coli in S. cerevisiae resulted in significantly increased ATPase activity, while neither genomic integration nor episomal expression of the $\beta$ subunit from Trichoderma reesei could enhance ATPase activity. When grown in minimal medium under anaerobic growth-coupled conditions, the strains expressing E. coli's $F_{1}$-ATPase genes showed significantly improved ethanol yield (increase of $10 \%$ compared to the control strain). However, elevated product formation reduces biomass formation and, therefore, volumetric productivity. We demonstrate that this negative effect can be overcome under growth-decoupled (nitrogen-starved) operation with high and constant biomass concentration. Under these conditions, which mimic the second (production) phase of a two-stage fermentation process, the ATPase-expressing strains showed significant improvement in volumetric productivity (up to 111\%) compared to the control strain.
\end{abstract}

Conclusions: Our study shows that expression of genes of the $F_{1}$-portion of E. coli's ATPase induces ATPase activity in S. cerevisiae and can be a promising way to improve ethanol production. This ATP-wasting strategy can be easily applied to other metabolites of interest, whose formation is coupled to ATP generation.

Keywords: Enforced ATP wasting, Ethanol, Saccharomyces cerevisiae, F,-ATPase, Metabolic engineering

\section{Background}

Fossil fuels currently still serve as the major energy and chemical source worldwide. Reliance on them has several drawbacks including limited availability, uneven distribution around the world and the production of greenhouse

\footnotetext{
*Correspondence: klamt@mpi-magdeburg.mpg.de

${ }^{\dagger}$ Ahmed Zahoor and Katrin Messerschmidt contributed equally to this work

Analysis and Redesign of Biological Networks, Max Planck Institute for Dynamics of Complex Technical Systems, Magdeburg, Germany
}

gas emissions upon combustion. Consequently, there has been an increasing interest in development of biofuels as alternative to fossil fuels. This can be achieved, for example, at a biorefinery where multiple feedstock components can be used for the sustainable production of biofuels as well as of other industrially relevant chemicals [1].

Bioethanol is the biggest product of biotechnology, both in terms of economy and volume. Worldwide annual production is currently more than 100 billion L and it is expected to cross 134 billion L by 2024 [2]. 
Saccharomyces cerevisiae is the predominant organism used for bioethanol production and there is great interest in generating superior production strains $[3,4]$ since merely a $1 \%$ increase in ethanol yield can already save the industry millions of dollars annually [5]. Some characteristics of $S$. cerevisiae that make it an ideal host for industrial production are efficient anaerobic ethanol production, tolerance to ethanol and other stress factors such as low $\mathrm{pH}$ as well as its insensitivity to bacteriophage infection.

Several approaches have been implemented to generate improved ethanol-producing S. cerevisiae strains. Many of these strategies seek to either reduce production of ATP or to increase ATP turnover (enforced ATP wasting) (Table 1). The rationale behind this approach is that ethanol synthesis and ATP production are coupled in both directions (ethanol synthesis delivers ATP and (balanced) ATP synthesis implies synthesis of ethanol) and a loss of ATP must be counter-balanced by the cell with increased synthesis of ATP and thus of ethanol. One example of a strategy to reduce the amount of ATP produced is the effort to replace the Embden-Meyerhof-Parnas (EMP) pathway (yielding two moles of ATP per mole glucose) with the Entner-Doudoroff (ED) pathway (yielding only one mole ATP) [6]. This mimics the situation in Zymomonas mobilis, which employs the ED instead of the EMP pathway and, as a consequence of the reduced ATP yield, exhibits extremely high glucose uptake rates $\left(60 \mathrm{mmol} \mathrm{g}^{-1} \mathrm{~h}^{-1}\right)$ and $97 \%$ of the maximal ethanol yield
[7]. The study [6] sought to implement the ED pathway in $S$. cerevisiae by expressing the corresponding genes from E. coli. However, one of the two enzymes required for this pathway (6-phosphogluconate dehydratase) failed to show activity despite several attempts to improve the iron-sulfur-cluster assembly which is critical for functioning of the enzyme [6].

Other studies showed that the use of alternative sugars (e.g., maltose or sucrose) or of alternative sugar transporters requiring more energy to transport the sugar into the cell may enhance the ethanol yield [5, 8-10]. Another approach to implement an ATP-wasting strategy is via the use of futile cycles, which are reaction cycles that result in net energy dissipation. In an E. coli lactate-producing strain, a futile cycle implemented by a combination of phosphoenolpyruvate synthase and pyruvate kinase, resulted in an increase of specific lactate productivity by almost $25 \%$ with a concomitant decrease in biomass yield of $26 \%$ [11, 12]. Similarly, in S. cerevisiae, two different futile cycles were tested for improvement of ethanol production. One consisted of a combined activity of phosphofructokinase and fructose-1,6-bisphosphatase resulting in an up to $9 \%$ improvement in ethanol titer. An alternative futile cycle based on the expression of pyruvate carboxylase and phosphoenolpyruvate carboxykinase genes also reported improved ethanol production per unit biomass in S. cerevisiae strains [13, 14].

Arguably, the simplest and most pragmatic method for enforced ATP wasting is the expression of a modified

Table 1 Overview of different ATP-wasting strategies applied in S. cerevisiae

\begin{tabular}{|c|c|c|c|c|c|c|c|}
\hline & $\begin{array}{l}\text { Benisch } \\
\text { and Boles [6] }\end{array}$ & $\begin{array}{l}\text { Semkiv et al. } \\
\text { [14] }\end{array}$ & $\begin{array}{l}\text { Semkiv et al. } \\
\text { [19] }\end{array}$ & Navas et al. [13] & Basso et al. [8] & $\begin{array}{l}\text { Jensen et al. [15, } \\
\text { 21] }\end{array}$ & This study \\
\hline $\begin{array}{l}\text { ATP-wasting } \\
\text { strategy }\end{array}$ & ED pathway & Futile cycle & $\begin{array}{l}\text { Alkaline phos- } \\
\text { phatase }\end{array}$ & Futile cycle & $\begin{array}{l}\text { Energy-depend- } \\
\text { ent substrate } \\
\text { uptake }\end{array}$ & $\begin{array}{l}F_{1} \text {-ATPase ( } \beta \\
\text { subunit) }\end{array}$ & $\begin{array}{c}F_{1} \text {-ATPase } \\
\text { (different } \\
\text { variants) }\end{array}$ \\
\hline Use of $F_{1}$-ATPase & No & No & No & No & No & Yes & Yes \\
\hline $\begin{array}{l}\text { Use of defined } \\
\text { (minimal) } \\
\text { medium }\end{array}$ & Yes & No & Yes & Yes & Yes & Yes & Yes \\
\hline $\begin{array}{l}\text { Detailed data on } \\
\text { physiology of } \\
\text { strains }^{\mathrm{a}}\end{array}$ & No & No & No & Yes & Yes & No & Yes \\
\hline $\begin{array}{l}\text { Anaerobic cultiva- } \\
\text { tion }\end{array}$ & No & No & No & No & Yes & No & Yes \\
\hline $\begin{array}{l}\text { ATP wasting for } \\
\text { growth-coupled } \\
\text { product forma- } \\
\text { tion }\end{array}$ & N.D. & Yes & Yes & Yes & Yes & Yes & Yes \\
\hline $\begin{array}{l}\text { ATP wasting for } \\
\text { growth-decou- } \\
\text { pled product } \\
\text { formation }\end{array}$ & N.D. & No & No & No & No & No & Yes \\
\hline
\end{tabular}

a Availability of comprehensive data on growth (biomass, growth rate), substrate utilization rates and production formation (titer, yield, and rates). N.D. not determined 
ATPase that can directly hydrolyze ATP. This approach was first implemented by Koebmann et al. $[15,16]$, who studied in E. coli the physiological effects of overexpressing the $\alpha, \beta$ and $\gamma$ subunit genes of the cytosolic $F_{1}$-portion of the ATPase catalyzing uncoupled ATP hydrolysis. Compared with other approaches, expression of such a single cytosolic ATP-hydrolyzing enzyme is less laborious and offers the additional benefit of not interfering with other intracellular metabolites as it directly hydrolyzes ATP to ADP. In prokaryotic hosts, expression of the cytosolic $F_{1}$-ATPase has recently been shown to improve the production of metabolites that are coupled to ATP generation. For example, overexpressing genes of the native $\mathrm{F}_{1}$-ATPase in E. coli improved titer, yield and specific productivities of the fermentation products under growth-coupled conditions, as well as volumetric productivity during two-stage fermentation [17]. Similarly, expression of the $\mathrm{F}_{1}$-ATPase led to improved acetoin production in an engineered Lactococcus lactis strain [18].

The use of different enzymes that consume ATP has also been tested for improving ethanol production in $S$. cerevisiae [14, 19-21], including the use of the $\beta$ subunit of the $\mathrm{F}_{1}$-portion of the ATPase from Trichoderma reesei [21]. However, these studies showed no or only minor enhancement of ethanol production or lack some critical information regarding the effect of such ATP wasting on the physiology of S. cerevisiae. Generally, we see the following drawbacks or gaps in earlier studies (Table 1): (a) the use of ATP-wasting mechanisms different from ATPase, which can interfere with central metabolism and may have unintended and unpredictable effects, (b) growth of strains in complex medium compromising yield calculations, (c) use of galactose as inducer (also used as carbon source by $S$. cerevisiae) again preventing unbiased yield and specific rate calculations, (d) comprehensive data on growth, substrate utilization rate and ethanol production (titer, yield, rates) are missing in most studies, and (e) growth-decoupled conditions were not considered.

Consequently, the aim of this study was to implement an ATP-wasting strategy in S. cerevisiae via the expression of genes of cytosolic ATPase enzyme(s) and to characterize the strains with respect to growth, ethanol production and substrate utilization. To this end, different variants of heterologous expression of genes of the $\mathrm{F}_{1}$-ATPase (or subunits of it) in S. cerevisiae were tested. As result, we found that episomal expression of the genes encoding the $\alpha \beta \gamma$ subunits of the $\mathrm{F}_{1}$-ATPase of $E$. coli results in significantly higher ATPase activity. Under anaerobic growth-coupled conditions, the ethanol titer and yield of these strains are significantly increased relatively to the control strain. The volumetric productivity decreased due to reduced biomass formation. In contrast, under growth-decoupled (nitrogen-starved) conditions with comparable biomass of the control and the ATPase strains, the volumetric productivity as well as specific production rates could be improved in comparison to the control strain.

\section{Results}

\section{Heterologous expression of ATPase genes in S. cerevisiae}

The objective of this study was to implement ATP wasting in S. cerevisiae by heterologous expression of genes of (suitable subunits of) an ATPase to improve ethanol production by the engineered strains. The $\mathrm{F}_{\mathrm{o}} \mathrm{F}_{1}$-ATP synthase (or ATPase) is a ubiquitous enzyme that is made up of two distinct parts; the membrane bound $\mathrm{F}_{\mathrm{o}}$ and the (water) soluble $F_{1}$-part, both of which exist in the form of rotary motors. The cytoplasmic $\mathrm{F}_{1}$-part consists of five different subunits with the stoichiometry $\alpha_{3} \beta_{3} \gamma \delta \varepsilon$ whereby the minimal composition of the rotary motor is $\alpha_{3} \beta_{3} \gamma$ [22]. Whereas both $\alpha$ and $\beta$ subunits can bind nucleotides, it is the $\beta$ subunit where catalysis takes place [23]. Therefore, the first ATPase variant selected for expression in $S$. cerevisiae was the $\mathrm{F}_{1}$-ATPase $\beta$ subunit from T. reesei, which, like $S$. cerevisiae, is a fungus. A previous patent application stated the use of $T$. reese $i$ and provided preliminary evidence for its effect on ethanol production in S. cerevisiae [21]. In contrast to the $S$. cerevisiae $\beta$ subunit, the T. reesei subunit lacks the mitochondrial signal peptide and hence can enable cytoplasmic ATPase activity.

Based on several positive reports [15-18, 24], the second and third variants of heterologous expression of $\mathrm{F}_{1}$-ATPase genes in $S$. cerevisiae are based on the E. coli $\mathrm{F}_{1}$-ATPase $\alpha, \beta$ and $\gamma$ subunits. We first considered separate expression of each subunit gene under control of a strong constitutive promoter and strong terminator (see "Materials and methods") as reported in the literature [25-27]. The yeast promoters and terminators are considerably longer (several hundred base pairs to more than $1 \mathrm{~kb})$ compared to their prokaryotic counterparts. When making constructs with several genes, as in the case of E. coli $\mathrm{F}_{1}$-ATPase subunits, the repetitive use of these cis-acting elements makes the cloning process cumbersome and can exert extra drain on the machinery of the host cell. One of the strategies to decrease the construct size is to use the viral $2 \mathrm{~A}$ sequences which are peptide sequences (usually up to 20 amino acids) that enable the expression of multiple genes from a polycistronic transcript and can thereby reduce the number of promoters needed. In recent years, several studies have reported the use of $2 \mathrm{~A}$ sequences for the expression of multiple genes in yeasts [28-30]. As the third ATPase expression variant used in this study, the $2 \mathrm{~A}$ sequences from Equine rhinitis 
B virus (ERBV-1) and Porcine teschovirus-1 (PTV) were used between the genes of the three $\alpha, \beta$ and $\gamma$ subunits of the E. coli $\mathrm{F}_{1}$-ATPase. This reduced the construct size by more than $27 \%$ compared to the variant where each subunit has its own cis-acting elements.

There has been a noticeable increase in the availability of toolboxs for genetic engineering of S. cerevisiae. Highly efficient CRISPR-Cas9-based methods are available for marker-free insertions and deletions in $S$. cerevisiae genome [31-34]. Therefore, as a first attempt, we inserted either a single copy of the $T$. reese $\mathrm{F}_{1}$-ATPase $\beta$ subunit gene (atp2) or the three E. coli $\mathrm{F}_{1}$-ATPase subunits joined via viral $2 \mathrm{~A}$ sequences into chromosome $\mathrm{X}$ of the prototrophic CEN.PK113-7D strain using the CRISPR-Cas9 marker-free kit [35] yielding strains 7D-atp2 and 7D-atp$A G D(2 \mathrm{~A})$, respectively. The parental (7D) and the transformed strains were grown in minimal medium, however, the transformed strains 7D-atp2 and 7D-atpAGD (2A) did not show significant ATPase activity and no effect on biomass or ethanol production compared to the parental strain could be observed (data not shown). Consequently, a plasmid-based approach was followed for all three variants and a yeast episomal plasmid pRSII326 carrying $2 \mu$ circle replication origin and cis-acting STB (stability) locus was used for high copy expression of the different $\mathrm{F}_{1}$-ATPase genes [36]. The transformation of the uracil auxotrophic S. cerevisiae CEN.PK113-5D strain with the plasmid carrying $T$. reesei subunit resulted in the strain 5D-atp2. Likewise, transforming the plasmids with the $\alpha, \beta$ and $\gamma$ subunit genes of $E$. coli with and without $2 \mathrm{~A}$ sequences into $S$. cerevisiae CEN.PK113-5D yielded the strains 5D-atpAGD and 5D-atpAGD (2A), respectively (see "Materials and methods").

The three plasmid-based ATPase strains were subsequently tested for functionality and for their effect on the production of ethanol under anaerobic growth-coupled and growth-decoupled (nitrogen-starved) conditions.

\section{Episomal expression of E. coli's $\mathrm{F}_{1}$-ATPase genes induces high ATPase activity in S. cerevisiae}

We determined the ATPase activity in the control (5D (E.V.)) and in the three constructed strains with episomal expression of the $F_{1}$-ATPase $\beta$ subunit gene of T. reesei (5D-atp2) and of the E. coli $\mathrm{F}_{1}$-ATPase $\alpha, \beta$ and $\gamma$ subunit genes (5D-atpAGD and 5D-atpAGD (2A)), respectively. The strains were grown in minimal medium, pellets were made during exponential phase and cell lysate was used for determining the ATPase activity.

Compared to the control strain 5D (E.V.), the two strains expressing the three subunit genes of the E. coli $\mathrm{F}_{1}$-ATPase exhibit a clear increase in ATPase activity (Fig. 1) by $78 \%$ and $103 \%$, respectively, which is in the range observed when overexpressing these genes directly

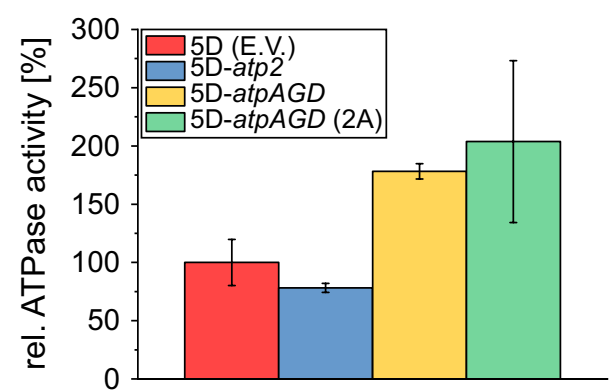

Fig. 1 ATPase activities of cell lysates of the constructed strains. The $p$ values for increased/decreased ATPase activity relative to the control strain are 0.1344 (5D-atp2), 0.0029 (5D-atpAGD) and 0.0677 (5D-atpAGD (2A)). The presented data are from triplicates and the error bars represent standard deviations

in E. coli [17]. In contrast, the ATPase activity even decreased by $21 \%$ in the strain expressing the $T$. reesei $\mathrm{F}_{1}$-ATPase $\beta$ subunit (5D-atp2), providing first evidence that this strain might not behave as intended.

\section{Effect of ATPase expression on growth-coupled ethanol production}

After determining functional activity upon episomal expression of the heterologous ATPases, the effect on biomass and especially ethanol production was determined under anaerobic growth-coupled conditions. Again, the strains 5D-atp2, 5D-atpAGD and 5D-atpAGD (2A) were tested and compared with the control strain with empty vector. The strains were cultivated in minimal medium with $0.4 \%$ glucose and incubated anaerobically at $30{ }^{\circ} \mathrm{C}$. Glucose uptake, biomass formation and production of ethanol and other byproducts were monitored and used to compute yields and specific consumption and production rates. To enable proper comparison, the specific rates were determined for identical time periods during exponential growth (from time point $2.5 \mathrm{~h}$ to $7 \mathrm{~h}$ for all strains; Fig. 2a-c; Table 2).

Despite the fact that the control strain already produces almost $80 \%$ of the maximal ethanol yield, heterologous expression of the $\mathrm{F}_{1}$-ATPases from $E$. coli significantly improved ethanol yield by more than $9 \%$ (5D-atpAGD) and 10\% (5D-atpAGD (2A)), respectively, while strain $5 \mathrm{D}$-atp 2 showed only a slight improvement of $2.5 \%$ (Fig. 2, Table 2). The specific glucose uptake rate is reduced in $5 \mathrm{D}$-atp 2 and $5 \mathrm{D}$-atpAGD, but is almost identical in $5 \mathrm{D}$-atpAGD (2A) enabling this strain to reach also a higher specific ethanol productivity ( $10 \%$ increase relative to control strain). Using simple flux balance calculations, we estimated the non-growth associated ATP maintenance demand (which includes the amount of ATP hydrolyzed by the $\mathrm{F}_{1}$-ATPase) in all four strains (Table 2). 

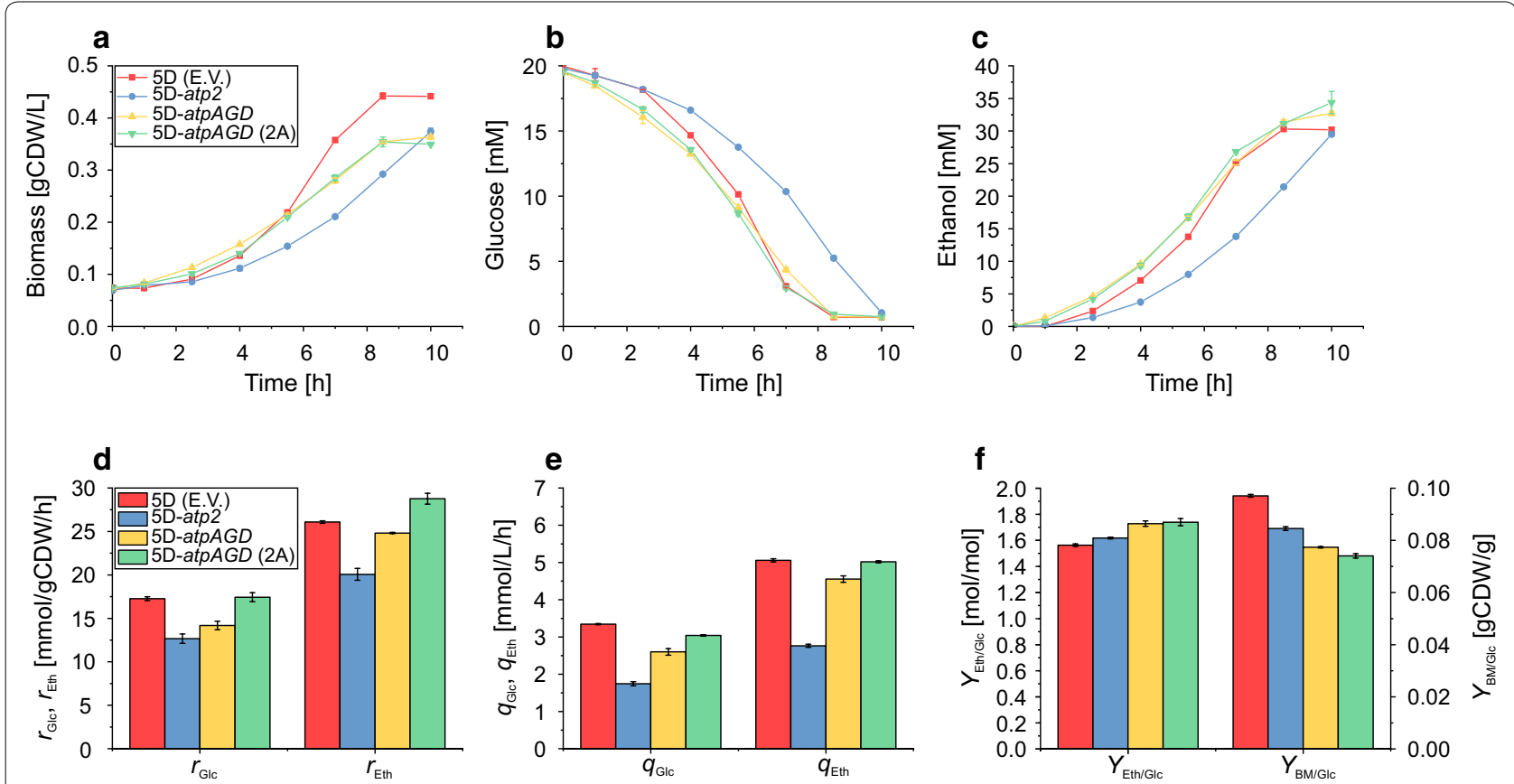

Fig. 2 Biomass formation (a), glucose consumption (b), ethanol production (c), specific glucose uptake rate/ethanol productivity (d), volumetric glucose uptake rate/ethanol productivity after $7 \mathrm{~h}(\mathbf{e})$ and ethanol and biomass yield (f) of the constructed strains under growth-coupled conditions. The data presented are from triplicates and the error bars represent standard deviations. Specific and volumetric rate values are reported for the period where all strains showed exponential growth (2.5-7 h). Yields are reported for the entire period of cultivation (0-10 h)

These values clearly correlate with the ethanol yield and reach the highest value $(9.59 \mathrm{mmol} / \mathrm{gCDW} / \mathrm{h})$ for strain $5 \mathrm{D}$-atpAGD (2A) compared to $0.30 \mathrm{mmol} / \mathrm{gCDW} / \mathrm{h}$ in the control strain.

As expected, ATPase expression had a significant impact on the biomass formation and growth rates (Fig. 2a, Table 2). The growth rate of the strains 5D-atp2 and $5 \mathrm{D}$-atpAGD dropped by $35 \%$ and that of strain $5 \mathrm{D}$-atpAGD (2A) by $26 \%$. A decrease in biomass corresponds to a decrease in biocatalyst for ethanol production and, consequently, the reduced biomass directly influenced the volumetric ethanol productivity, which was cut down by $45 \%$ and $10 \%$ for strains 5D-atp 2 and $5 \mathrm{D}$-atp $A G D$, respectively, but only by $1 \%$ for $5 \mathrm{D}$-atp $A G D$ (2A). Clearly, while yields and specific productivities will be less affected, the relative changes in the volumetric productivities will depend on the total runtime (i.e., the amount of substrate used) of the respective cultivation. For longer cultivations, it can be expected that the volumetric productivity improves faster for the control strain due to the faster accumulation of biomass.

\section{Effect of ATPase expression on growth-decoupled (nitrogen-starved) ethanol production}

The reduced volumetric productivity, observed despite improved product yield and partially improved specific productivities, is a well-documented effect of enforced ATP wasting as more product is made at the expense of biomass [11, 17, 18, 37]. Similar as in [17], we hypothesized that this trade-off can be overcome if growth and production are separated. This was tested in a growthdecoupled (nitrogen-starved) approach in which the strains were inoculated with a higher starting $\mathrm{OD}_{600}$ of ca. 2.5 (vs. ca. 0.2 used in the growth-coupled approach) in a minimal medium lacking the nitrogen source. The strains were then incubated at $30{ }^{\circ} \mathrm{C}$ and biomass, ethanol production as well as glucose uptake was monitored. It is important to note that yeast cells typically continue to grow for a while even upon nitrogen starvation. Here, protein degradation pathways and proteasome play a major role in nitrogen recycling via extensive degradation of RNA and proteins [38-41]. To minimize biomass formation under nitrogen starvation, the cells grown on minimal medium (containing nitrogen) were first precultured in a medium without nitrogen (to deplete cellular nitrogen reservoirs) before transfer to the final nitrogen-starved medium (see "Materials and methods").

With this protocol, we observe that all strains show nearly constant biomass concentrations over the course of the cultivation $(10 \mathrm{~h})$, although a slight increase can be seen for 5D-atpAGD (2A) during the first $4 \mathrm{~h}$ (Fig. 3). Under these growth-decoupled conditions, the specific 
Table 2 Biomass, glucose uptake and production of ethanol, glycerol and acetate of the constructed S. cerevisiae strains under anaerobic conditions

\begin{tabular}{|c|c|c|c|c|}
\hline & 5D (E.V.) & 5D-atp2 & 5D-atpAGD & 5D-atpAGD (2A) \\
\hline $\begin{array}{l}\mu \\
{\left[h^{-1}\right]}\end{array}$ & $0.316 \pm 0.005$ & $\begin{array}{l}0.201 \pm 0.006 \\
(p<0.0001)\end{array}$ & $\begin{array}{l}0.202 \pm 0.003 \\
(p<0.0001)\end{array}$ & $\begin{array}{l}0.235 \pm 0.003 \\
(p<0.0001)\end{array}$ \\
\hline $\begin{array}{l}Y_{\text {BM/GlC }} \\
{[g C D W / g]}\end{array}$ & $0.0971 \pm 0.0007$ & $\begin{array}{l}0.0845 \pm 0.0009 \\
(p<0.0001)\end{array}$ & $\begin{array}{l}0.0774 \pm 0.0003 \\
(p<0.0001)\end{array}$ & $\begin{array}{l}0.0741 \pm 0.0010 \\
(p<0.0001)\end{array}$ \\
\hline $\begin{array}{l}r_{\mathrm{Glc}} \\
{[\mathrm{mmol} / \mathrm{gCDW} / \mathrm{h}]}\end{array}$ & $17.26 \pm 0.27$ & $\begin{array}{l}12.66 \pm 0.66 \\
(p=0.0004)\end{array}$ & $\begin{array}{l}14.18 \pm 0.60 \\
(p=0.0012)\end{array}$ & $\begin{array}{l}17.44 \pm 0.63 \\
(p=0.6712)\end{array}$ \\
\hline $\begin{array}{l}q_{\mathrm{Glc}} \\
{[\mathrm{mmol} / \mathrm{L} / \mathrm{h}]}\end{array}$ & $3.35 \pm 0.02$ & $\begin{array}{l}1.74 \pm 0.07 \\
(p<0.0001)\end{array}$ & $\begin{array}{l}2.60 \pm 0.11 \\
(p=0.0003)\end{array}$ & $\begin{array}{l}3.04 \pm 0.03 \\
(p<0.0001)\end{array}$ \\
\hline $\begin{array}{l}r_{\text {Eth }} \\
{[\mathrm{mmol} / \mathrm{gCDW} / \mathrm{h}]}\end{array}$ & $26.09 \pm 0.18$ & $\begin{array}{l}20.07 \pm 0.84 \\
(p=0.0003)\end{array}$ & $\begin{array}{l}24.82 \pm 0.10 \\
(p=0.0004)\end{array}$ & $\begin{array}{l}28.77 \pm 0.76 \\
(p=0.0040)\end{array}$ \\
\hline $\begin{array}{l}q_{\mathrm{Eth}} \\
{[\mathrm{mmol} / \mathrm{L} / \mathrm{h}]}\end{array}$ & $5.06 \pm 0.05$ & $\begin{array}{l}2.76 \pm 0.05 \\
(p<0.0001)\end{array}$ & $\begin{array}{l}4.55 \pm 0.10 \\
(p=0.0018)\end{array}$ & $\begin{array}{l}5.02 \pm 0.03 \\
(p=0.3346)\end{array}$ \\
\hline $\begin{array}{l}Y_{\text {Eth/Glc }} \\
{[\mathrm{mol} / \mathrm{mol}]}\end{array}$ & $1.58 \pm 0.01$ & $\begin{array}{l}1.62 \pm 0.01 \\
(p=0.0042)\end{array}$ & $\begin{array}{l}1.73 \pm 0.03 \\
(p=0.0007)\end{array}$ & $\begin{array}{l}1.74 \pm 0.03 \\
(p=0.0014)\end{array}$ \\
\hline $\begin{array}{l}r_{\text {Gly }} \\
{[\mathrm{mmol} / \mathrm{gCDW} / \mathrm{h}]}\end{array}$ & $3.90 \pm 0.22$ & $\begin{array}{l}2.89 \pm 0.24 \\
(p=0.0059)\end{array}$ & $\begin{array}{l}2.49 \pm 0.16 \\
(p=0.0009)\end{array}$ & $\begin{array}{l}3.39 \pm 0.04 \\
(p=0.0172)\end{array}$ \\
\hline $\begin{array}{l}Y_{G \mid \mathrm{ly} / \mathrm{Glc}} \\
{[\mathrm{mol} / \mathrm{mol}]}\end{array}$ & $0.220 \pm 0.003$ & $\begin{array}{l}0.201 \pm 0.004 \\
(p=0.0040)\end{array}$ & $\begin{array}{l}0.162 \pm 0.006 \\
(p=0.0001)\end{array}$ & $\begin{array}{l}0.185 \pm 0.003 \\
(p<0.0001)\end{array}$ \\
\hline $\begin{array}{l}r_{A c} \\
{[\mathrm{mmol} / \mathrm{gCDW} / \mathrm{h}]}\end{array}$ & n.d. & n.d. & n.d. & n.d. \\
\hline $\begin{array}{l}Y_{\text {Ac/Glc }} \\
{[\mathrm{mol} / \mathrm{mol}]}\end{array}$ & n.d. & n.d. & n.d. & n.d. \\
\hline $\begin{array}{l}r_{\text {ATP-NGAM }} \\
{[\mathrm{mmol} / \mathrm{gCDW} / \mathrm{h}]}\end{array}$ & 0.30 & 3.66 & 8.33 & 9.59 \\
\hline
\end{tabular}

Specific and volumetric rates are reported for the period where all strains showed exponential growth (2.5-7 h; see Fig. 2). The values of the yields are reported for the entire cultivation period $(0-10 \mathrm{~h})$. The data are from triplicate experiments and the error ranges represent standard deviations. $p$ values for a two-sample $t$ test are given with respect to the control strain 5D (E.V.) indicating whether a significant change has occurred

$Y_{\mathrm{BM} / \mathrm{Gl},}$ biomass yield; $r_{\mathrm{Gl}, c}$ specific glucose uptake rate; $q_{\mathrm{Gl},}$, volumetric glucose uptake rate; $r_{\mathrm{Eth}}$, specific ethanol production rate; $q_{\mathrm{Eth}}$, volumetric ethanol productivity; $Y_{\text {Eth/Glc }}$ ethanol yield; $r_{\mathrm{Gly}}$ specific glycerol production rate; $Y_{\mathrm{Gly} / \mathrm{Gl} c^{\prime}}$ glycerol yield; $r_{\mathrm{Ac}}$, specific acetate production rate; $Y_{\mathrm{Ac} / \mathrm{Gl} c^{\prime}}$ acetate yield; $r_{\mathrm{ATP}-\mathrm{NGAM}}$, non-growth-

associated ATP maintenance demand (estimated from flux balance calculations)

glucose uptake rate and specific ethanol production rate of the two strains 5D-atpAGD and 5D-atpAGD (2A) expressing the three ATPase subunit genes from E. coli are significantly higher than in the control strain. Consequently, as hypothesized, the volumetric productivity of these strains shows a relative improvement of more than $44 \%$ and $111 \%$, respectively, thus overcoming the negative impact of reduced biomass on volumetric productivity. The increased specific and volumetric ethanol productivities can again be explained by the higher ATP turnover as indicated by the estimated non-growth-associated ATP maintenance demand (Table 3). In contrast, and in agreement with the growth-coupled experiments, expression of the $\beta$-subunit from $T$. reesei was not beneficial and even reduced specific as well as volumetric productivity. At the same time, the ethanol yield was again higher in all ATPase-expressing strains compared to the control strain.

To sum up, our experimental results provide a conclusive evidence of activity of E. coli $\mathrm{F}_{1}$-ATPase in S. cerevisiae and its beneficial impact on ethanol production under anaerobic growth-coupled (especially on ethanol yield) and growth-decoupled (especially on productivity) conditions.

\section{Discussion}

Enforced ATP wasting has been recognized as a promising metabolic engineering strategy to enhance the microbial production of metabolites [11, 17, 18, 42-44] and it also appears to be suitable to improve production of ethanol by yeast. Along this line, we extended and complemented previous studies by (1) constructing yeast strains that overproduce ATPase (subunits) yielding sufficient ATPase activity, and (2) using those strains to comprehensively study the effect of ATPase expression in S. cerevisiae on growth, substrate utilization as well as ethanol production in defined (minimal) medium.

ATPase activity in S. cerevisiae was enabled via the expression of $\mathrm{F}_{1}$-ATPase genes from either T. reesei $(\beta$ subunit as originally proposed in [21]) in strain 5D-atp2 or from $E$. coli $(\alpha \beta \gamma$ subunits as previously used in $[15,17$, 18]). The subunit genes of the E. coli ATPase were placed either under the control of single promoters in strain $5 \mathrm{D}$-atpAGD or joined via viral $2 \mathrm{~A}$ sequences to enable 

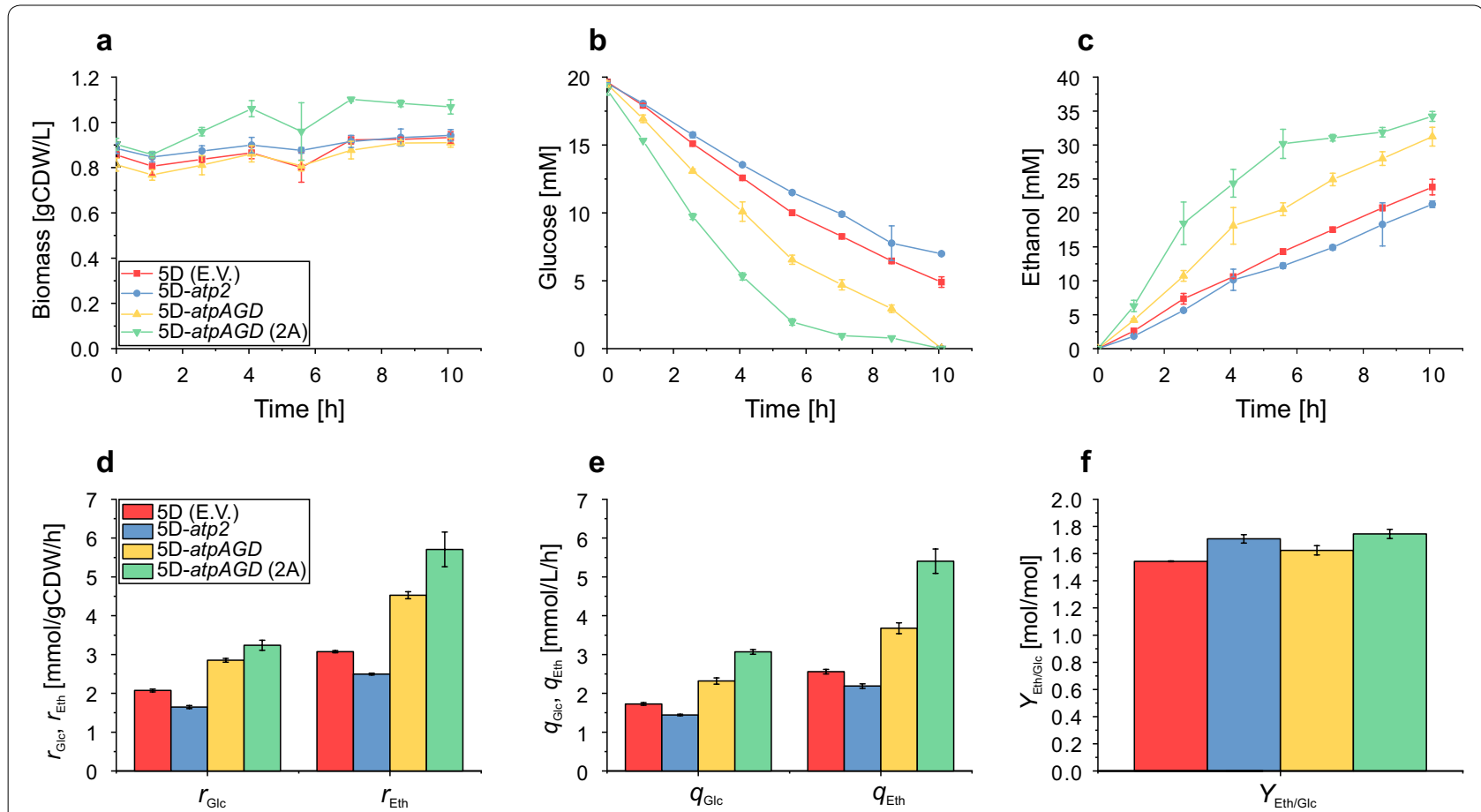

Fig. 3 Biomass formation (a), glucose consumption (b), ethanol production (c), specific glucose uptake rate/ethanol productivity (d), volumetric glucose uptake rate/ethanol productivity after $5.5 \mathrm{~h}(\mathbf{e})$ and ethanol yield $(\mathbf{f})$ of the different strains under growth-decoupled (nitrogen-starved) conditions. Specific and volumetric rate values are reported for the first $5.5 \mathrm{~h}$ of cultivation. Yields are reported for the entire cultivation period $(0-10$ h). The data presented are from triplicates and the error bars represent standard deviations

polycistronic expression in strain 5D-atpAGD (2A). Genomic integration of single copies of these ATPase genes did not lead to significant ATPase activity for any of the variants tested. One possible reason is the low copy number; another explanation could be that the chosen X2 locus [35] was not suitable to achieve sufficiently high expression rates. In contrast, significant enzymatic ATPase activities could be measured for plasmid-based expression of $E$. coli's $\mathrm{F}_{1}$-ATPase genes in the two strains 5D-atpAGD and 5D-atpAGD (2A), both with comparable activity levels. We could not find such a conclusive proof of a functional ATPase activity in previous studies. For example, whereas the expression of a ribosome-associated molecular chaperone with ATP-hydrolyzing activity improved ethanol production on glucose and galactose as substrate, the enzymatic activity of ATP hydrolysis was reported to be reduced by almost $20 \%$; similarly the expression of ATP-degrading apyrase enzyme showed a $20 \%$ improvement in enzymatic activity of ATP hydrolysis but did not result in improvement of ethanol production by the engineered strains [14].

In our experiments, neither genomic integration nor episomal expression of the genes of the $\beta$ subunit of the ATPase from T. reesei led to enhanced ATPase activity or to a phenotype that would be consistent with increased ATPase activity. In the original work suggesting the heterologous production of the $\beta$ subunit of T. reesei's $\mathrm{F}_{1}$-ATPase to increase ATP drain in S. cerevisiae [21], ATPase activities were not measured and only a minor increase in ethanol production was reported. Together with our experimental data on metabolic fluxes and yields, which indicate a typical phenotype of a strain overexpressing a (metabolically inactive) protein (reduced growth rate, only slightly reduced biomass yield), we, therefore, postulate that the $\beta$ subunit is indeed produced in strain 5D-atp 2 but does not have functional ATPase activity.

As one key result, our study proves a beneficial effect of expressing E. coli's $\mathrm{F}_{1}$-ATPase on ethanol production by engineered $S$. cerevisiae strains. Under growth-coupled conditions, the ethanol yield significantly improved for strains expressing ATPase because a larger fraction of the substrate is used for synthesizing ATP (coupled to ethanol synthesis). However, for the same reason, enforced ATP wasting results in a reduced growth and biomass formation. This implies that less biocatalyst is available for ethanol production compared to the control strain which has up to $26 \%$ more biomass for ethanol production (Table 2) leading to higher volumetric productivities by the control strain. This drawback, however, can 
Table 3 Growth rate, glucose uptake and production of ethanol, glycerol and acetate of the constructed S. cerevisiae strains under growth-decoupled (nitrogen-starved) cultivation

\begin{tabular}{|c|c|c|c|c|}
\hline & 5D (E.V.) & 5D-atp2 & 5D-atpAGD & 5D-atpAGD (2A) \\
\hline $\begin{array}{l}\mu \\
{\left[h^{-1}\right]}\end{array}$ & $\sim 0$ & $\sim 0$ & $\sim 0$ & $\sim 0$ \\
\hline $\begin{array}{l}r_{\mathrm{Glc}} \\
{[\mathrm{mmol} / \mathrm{gCDW} / \mathrm{h}]}\end{array}$ & $2.07 \pm 0.05$ & $\begin{array}{l}1.65 \pm 0.05 \\
(p=0.0004)\end{array}$ & $\begin{array}{l}2.85 \pm 0.06 \\
(p<0.0001)\end{array}$ & $\begin{array}{l}3.24 \pm 0.16 \\
(p=0.0003)\end{array}$ \\
\hline $\begin{array}{l}9_{\mathrm{Glc}} \\
{[\mathrm{mmol} / \mathrm{L} / \mathrm{h}]}\end{array}$ & $1.73 \pm 0.04$ & $\begin{array}{l}1.44 \pm 0.02 \\
(p=0.0004)\end{array}$ & $\begin{array}{l}2.32 \pm 0.10 \\
(p=0.0007)\end{array}$ & $\begin{array}{l}3.07 \pm 0.08 \\
(p<0.0001)\end{array}$ \\
\hline $\begin{array}{l}r_{\text {Eth }} \\
{[\mathrm{mmol} / \mathrm{gCDW} / \mathrm{h}]}\end{array}$ & $3.07 \pm 0.03$ & $\begin{array}{l}2.50 \pm 0.03 \\
(p<0.0001)\end{array}$ & $\begin{array}{l}4.53 \pm 0.11 \\
(p<0.0001)\end{array}$ & $\begin{array}{l}5.71 \pm 0.55 \\
(p=0.0011)\end{array}$ \\
\hline $\begin{array}{l}q_{\mathrm{Eth}} \\
{[\mathrm{mmol} / \mathrm{L} / \mathrm{h}]}\end{array}$ & $2.56 \pm 0.07$ & $\begin{array}{l}2.19 \pm 0.07 \\
(p=0.0033)\end{array}$ & $\begin{array}{l}3.68 \pm 0.17 \\
(p=0.0005)\end{array}$ & $\begin{array}{l}5.40 \pm 0.38 \\
(p=0.0002)\end{array}$ \\
\hline $\begin{array}{l}Y_{\text {Eth/Glc }} \\
{[\mathrm{mol} / \mathrm{mol}]}\end{array}$ & $1.54 \pm 0.00$ & $\begin{array}{l}1.71 \pm 0.04 \\
(p=0.0017)\end{array}$ & $\begin{array}{l}1.62 \pm 0.04 \\
(p=0.0294)\end{array}$ & $\begin{array}{l}1.75 \pm 0.04 \\
(p=0.0011)\end{array}$ \\
\hline $\begin{array}{l}r_{\text {Gly }} \\
{[\mathrm{mmol} / \mathrm{gCDW} / \mathrm{h}]}\end{array}$ & $0.386 \pm 0.017$ & $\begin{array}{l}0.331 \pm 0.005 \\
(p=0.0058)\end{array}$ & $\begin{array}{l}0.444 \pm 0.009 \\
(p=0.0060)\end{array}$ & $\begin{array}{l}0.490 \pm 0.011 \\
(p=0.0008)\end{array}$ \\
\hline $\begin{array}{l}Y_{\mathrm{Gly} / \mathrm{Gl}} \\
{[\mathrm{mol} / \mathrm{mol}]}\end{array}$ & $0.172 \pm 0.003$ & $\begin{array}{l}0.192 \pm 0.005 \\
(p=0.0039)\end{array}$ & $\begin{array}{l}0.138 \pm 0.005 \\
(p=0.0006)\end{array}$ & $\begin{array}{l}0.144 \pm 0.002 \\
(p=0.0002)\end{array}$ \\
\hline $\begin{array}{l}r_{\mathrm{AC}} \\
{[\mathrm{mmol} / \mathrm{gCDW} / \mathrm{h}]}\end{array}$ & $0.0503 \pm 0.0041$ & $\begin{array}{l}0.0413 \pm 0.0108 \\
(p=0.2506)\end{array}$ & $\begin{array}{l}0.0666 \pm 0.0109 \\
(p=0.0713)\end{array}$ & $\begin{array}{l}0.0779 \pm 0.0058 \\
(p=0.0025)\end{array}$ \\
\hline $\begin{array}{l}Y_{\mathrm{Ac} / \mathrm{Glc}} \\
{[\mathrm{mol} / \mathrm{mol}]}\end{array}$ & $0.0198 \pm 0.0014$ & $\begin{array}{l}0.0228 \pm 0.0041 \\
(p=0.2931)\end{array}$ & $\begin{array}{l}0.0230 \pm 0.0038 \\
(p=0.2309)\end{array}$ & $\begin{array}{l}0.0249 \pm 0.0028 \\
(p=0.0443)\end{array}$ \\
\hline $\begin{array}{l}r_{\text {ATP-NGAM }} \\
{[\mathrm{mmol} / \mathrm{gCDW} / \mathrm{h}]}\end{array}$ & 2.88 & 2.33 & 4.31 & 5.47 \\
\hline
\end{tabular}

Specific and volumetric rate values are reported for the first $5.5 \mathrm{~h}$ of cultivation. Yields are reported for the entire period of cultivation (0-10 $\mathrm{h}$ ). The data are from triplicate experiments and the error ranges represent standard deviations. $p$ values for a two-sample $t$ test are given with respect to the control strain $5 \mathrm{D}$ (E.V.) indicating whether a significant change has occurred

$Y_{\mathrm{BM} / \mathrm{Gl} \mathrm{c}^{\prime}}$ biomass yield; $r_{\mathrm{Gl} c^{\prime}}$ specific glucose uptake rate; $q_{\mathrm{Gl} c^{\prime}}$ volumetric glucose uptake rate; $r_{\mathrm{Eth}}$, specific ethanol production rate; $q_{\mathrm{Eth}}$, volumetric ethanol productivity; $Y_{\text {Eth/Glc }}$, ethanol yield; $r_{\mathrm{Gly}}$ specific glycerol production rate; $Y_{\mathrm{Gly} / \mathrm{Gl} c^{\prime}}$ glycerol yield; $r_{\mathrm{Ac}}$ specific acetate production rate $\gamma_{\mathrm{Ac} / \mathrm{Gl} c^{\prime}}$ acetate yield; $r_{\mathrm{ATP}-\mathrm{NGAM}}$, non-growthassociated ATP maintenance demand (estimated from flux balance calculations)

be overcome by two-stage fermentations where growth and production are decoupled. As a proof-of-principle for such an approach, we showed that growth-decoupled (nitrogen-starved) production, where the biomass of both the control and ATPase-expressing strains are comparable, the yield, specific productivity as well as the volumetric productivity of the ATPase-expressing strains were considerably improved (Fig. 3 , Table 3 ). The positive impact of ATP wasting during growth-decoupled production phase was also discussed in a recent theoretical study [37]. Interestingly, even though there are several studies on ATP wasting and its impact on improved metabolite production in both prokaryotic as well as eukaryotic hosts, data on application of ATPwasting techniques on growth-arrested cells in literature are scarce; only recently the potential of ATP wasting to improve product synthesis during growth-decoupled conditions was studied in E. coli [17].

Our study thus demonstrates that enforced ATP wasting in yeast can either be used to increase ethanol yield (especially under growth-coupled conditions) or for improving the volumetric productivity of ethanol synthesis with high yield under growth-decoupled conditions where the negative effect of ATPase activity on growth is not relevant. This trade-off between yield and volumetric productivity should be considered specifically for each application. A two-stage cultivation with separated growth and production phase comes at the cost of producing biomass in the beginning, which is overcome in the production phase in terms of higher productivity. The use of immobilized cells or their reuse via retention can further help to minimize these drawbacks.

Expression of ATPase usually also affects substrate uptake rate. In $E$. coli, expression of the $\mathrm{F}_{1}$-ATPase genes resulted in an increase in specific glucose uptake rate of more than $18 \%$ and $130 \%$ under growth-coupled and growth-decoupled conditions, respectively, which contributes to the observed increased specific productivity in E. coli [17]. In the two yeast strains with increased ATPase activity, an increase in specific glucose uptake rates of $37-56 \%$ was also observed under growth-decoupled conditions (Table 3), whereas no significant change or even a decrease could be seen under growth-coupled conditions. Thus, compared to E. coli, it seems that $S$. cerevisiae might have a reduced capacity (or regulatory hurdles) to counteract the loss of ATP by increasing 
its glycolytic flux for enhanced ATP synthesis during growth, similar as it has been reported for Lactococcus lactis [15]. Generally, from the two strains expressing E. coli's $\mathrm{F}_{1}$-ATPase genes, the strain with polycistronic expression (5D-atpAGD (2A)) consistently showed slightly higher ATPase activity and superior ethanol production performance compared to strain 5D-atpAGD with single promotors for each gene. This indicates that the polycistronic expression may lead to a higher level of active $\mathrm{F}_{1}$-ATPase.

\section{Conclusions}

We have successfully constructed yeast strains overexpressing ATPase genes and showed that the resulting increased ATPase activity leads to beneficial effects on ethanol yield or volumetric ethanol production, depending on the chosen process type. The plasmids generated in this work offer a simple and practical way to enforce ATP wasting in S. cerevisiae and can be easily employed in other applications. Even though this study aims to provide a proof-of-principle for the application of enforced ATP wasting in yeast, the use of auxotrophic markers makes these plasmids also attractive for industrial use owing to their stability in yeast cells [45].

In future work, it will be interesting to study effects of ATP wasting in S. cerevisiae with substrates other than glucose (such as maltose, sucrose) or to improve the production of other target metabolites that are coupled to energy generation. Those studies will help to uncover the full potential of enforced ATP wasting as a valuable tool for metabolic engineering of yeast cells.

\section{Materials and methods}

\section{Strain construction and plasmids}

Expression cassettes of the three ATPase variants used in this study were synthesized by GeneArt (Thermo Fisher Scientific) and were directly cloned into the corresponding target-vector. The Easyclone marker-less intergrative vector set for $S$. cerevisiae using CRISPR-Cas9 was employed for genomic integration of the ATPase encoding genes at $\mathrm{X} 2$ locus as described in the user manual [35]. The plasmids expressing Cas9 and helper gRNA were removed by growing the cells on non-selective medium. Successful integration at X2 locus was confirmed via colony PCR using primers according to the protocol [35]. For episomal expression, pRSII326 [36] was used and purchased from Addgene.

Viral 2A peptide sequences were used to enable polycistronic expression of the E. coli ATPase in S. cerevisiae. In a recent study comparing more than 20 different $2 \mathrm{~A}$ peptide sequences, the $2 \mathrm{~A}$ peptides from Equine rhinitis $B$ virus (ERBV-1) and Porcine teschovirus-1 (PTV) showed the best cleavage efficiency in S. cerevisiae [30] and were chosen for use in this study. The ERBV-1 peptide sequence was used between the $\operatorname{atp} A$ and $\operatorname{atp} G$ whereas the PTV peptide sequence was used between the $\operatorname{atp} G$ and $a t p D$.

The sequences of the ATPase constructs are provided in Additional file 1 and all strains and plasmids used in this study are listed in Table 4.

\section{Cultivation conditions}

Overnight cultures of the yeast strains were routinely grown aerobically at $30{ }^{\circ} \mathrm{C}$ (shaker with shaking amplitude of $50 \mathrm{~mm}$ and $190 \mathrm{rpm})$ in SD-URA $(6.7 \mathrm{~g} / \mathrm{L}$ yeast nitrogen base without amino acids, $1.92 \mathrm{~g} / \mathrm{L}$ URA dropout medium). The overnight culture was centrifuged and washed using water before inoculating the final medium with a given $\mathrm{OD}_{600}$. The experiments to analyze the effect of ATPase expression were performed in mineral salt medium [46] with the following composition: $5 \mathrm{~g} / \mathrm{L}$ $\left(\mathrm{NH}_{4}\right)_{2} \mathrm{SO}_{4}, 3 \mathrm{~g} / \mathrm{L} \mathrm{KH}_{2} \mathrm{PO}_{4}$, and $0.5 \mathrm{~g} / \mathrm{L} \mathrm{MgSO}_{4} \cdot 7 \mathrm{H}_{2} \mathrm{O}$. Trace elements and vitamins were added to the medium and their $1000 \times$ stock was prepared with following compositions. $1000 \times$ trace elements stock: $15 \mathrm{~g} / \mathrm{L}$ $\mathrm{Na}_{2}$ EDTA, $4.5 \mathrm{~g} / \mathrm{L} \quad \mathrm{ZnSO}_{4} \cdot 7 \mathrm{H}_{2} \mathrm{O}, 1 \mathrm{~g} / \mathrm{L} \quad \mathrm{MnCl}_{2} \cdot 2 \mathrm{H}_{2} \mathrm{O}$, $0.3 \mathrm{~g} / \mathrm{L} \quad \mathrm{CoCl}_{2} \cdot 6 \mathrm{H}_{2} \mathrm{O}, 0.3 \mathrm{~g} / \mathrm{L} \quad \mathrm{CuSO}_{4} \cdot 5 \mathrm{H}_{2} \mathrm{O}, 0.4 \mathrm{~g} / \mathrm{L}$ $\mathrm{Na}_{2} \mathrm{MoO}_{4} \cdot 2 \mathrm{H}_{2} \mathrm{O}, 4.5 \mathrm{~g} / \mathrm{L} \mathrm{CaCl} 2 \cdot 2 \mathrm{H}_{2} \mathrm{O}, 3 \mathrm{~g} / \mathrm{L} \mathrm{FeSO}{ }_{4} \cdot 7 \mathrm{H}_{2} \mathrm{O}$, $1 \mathrm{~g} / \mathrm{L} \mathrm{H}_{3} \mathrm{BO}_{3}$ and $0.1 \mathrm{~g} / \mathrm{L}$ KI. $1000 \times$ vitamins stock: $0.05 \mathrm{~g} / \mathrm{L}$ D-biotin, $1 \mathrm{~g} / \mathrm{L}$ Ca-D-pantothenate, $1 \mathrm{~g} / \mathrm{L}$ nicotinic acid, $25 \mathrm{~g} / \mathrm{L}$ myo-inositol, $1 \mathrm{~g} / \mathrm{L}$ thiamine hydroxychloride, $1 \mathrm{~g} / \mathrm{L}$ pyridoxine hydrochloride, and $0.2 \mathrm{~g} / \mathrm{L}$ $p$-aminobenzoic acid. For experiments under anaerobic conditions, the mineral salt medium was additionally supplemented with ergosterol $(7 \mathrm{mg} / \mathrm{L})$ and Tween 80 (1:1200) as described previously [47]. For experiments on growth-decoupled (nitrogen-starved) ethanol production, $\left(\mathrm{NH}_{4}\right)_{2} \mathrm{SO}_{4}$ was left out of the medium to suppress biomass formation. Furthermore, cultures were preadapted to anaerobic conditions and nitrogen-starved to empty intracellular nitrogen reservoirs before actual measurements started. Therefore, aerobic overnight cultures in SD-URA (2\% glucose) were centrifuged, washed with water, and inoculated into minimal medium with nitrogen ( $2 \%$ glucose). After $6-8 \mathrm{~h}$ of anaerobic cultivation at $30{ }^{\circ} \mathrm{C}$, cells were centrifuged, washed with water, and inoculated into minimal medium without nitrogen ( $2 \%$ glucose). After growth arrest (10-11 h anaerobic cultivation at $30{ }^{\circ} \mathrm{C}$ ) cells were centrifuged, washed with water, and inoculated into minimal medium without nitrogen ( $0.4 \%$ glucose) for measurement of glucose consumption and ethanol production for $10 \mathrm{~h}$ of anaerobic cultivation at $30^{\circ} \mathrm{C}$.

For anaerobic cultivation, $50-\mathrm{ml}$ cultivation tubes (Falcon) with screw cap were used, filled with $30-50 \mathrm{~mL}$ cultivation medium and incubated at $30{ }^{\circ} \mathrm{C}$ with stirring 
Table 4 Strains and plasmids used in this study

\begin{tabular}{|c|c|c|}
\hline & Description & Reference \\
\hline \multicolumn{3}{|l|}{ Strain } \\
\hline $7 \mathrm{D}$ & S. cerevisiae CEN.PK1 13-7D. MATa; URA3; TRP1; LEU2; HIS3; MAL2-8C; SUC2 & Euroscarf \\
\hline 7D-atp2 & 7D with genomic integration of the T. reesei ATPase $\beta$ subunit gene atp2 (pTEF1-atp2-tCYC1) at X2 locus & This study \\
\hline 7D-atpAGD (2A) & $\begin{array}{l}\text { 7D with genomic integration of the } E \text {. coli ATPase } \alpha, \beta \text { and } \gamma \text { subunit genes atpAGD joined via viral 2A peptides at } \\
X 2 \text { locus }\end{array}$ & This study \\
\hline $5 \mathrm{D}$ & S. cerevisiae CEN.PK113-5D. MATa; ura3-52; TRP1; LEU2; HIS3; MAL2-8C; SUC2 & Euroscarf \\
\hline 5D (E.V.) & $5 \mathrm{D}$ transformed with the empty vector pRSII326 & This study \\
\hline 5D-atp2 & 5D transformed with pRSII326-atp2 & This study \\
\hline 5D-atpAGD & 5D transformed with pRSII326-atpAGD & This study \\
\hline $5 D-\operatorname{atp} A G D(2 A)$ & $5 \mathrm{D}$ transformed with $\mathrm{pRS} \| 326-\operatorname{atp} A G D(2 \mathrm{~A})$ & This study \\
\hline \multicolumn{3}{|l|}{ Plasmids } \\
\hline pCfB2312 & Cas9 Expression Vector & {$[35]$} \\
\hline pCfB2899 & EasyClone-MarkerFree Integrative Vector for insertion into Chromosome X: 194944...195980 (X2 locus) & {$[35]$} \\
\hline pCfB3020 & EasyClone-MarkerFree gRNA Helper Vector for insertion into X2 locus & {$[35]$} \\
\hline pCfB2899-atp2 & pCfB2899 carrying the T. reesei ATPase $\beta$ subunit gene atp2 (pTEF1-atp2-tCYC1) & This study \\
\hline pCfB2899-atpAGD (2A) & $\begin{array}{l}\text { pCfB2899 carrying the E. coli ATPase } \alpha \beta \text { and } \gamma \text { subunit genes atpAGD joined with viral } 2 \text { A peptide sequences } \\
\text { under the control of TEF1 promoter }\end{array}$ & This study \\
\hline pRSIII326 & Shuttle vector with URA3 marker and $2 \mu$ ORI-STB. Addgene ID: 35469 & [36] \\
\hline pRSII326-atp2 & pRSII326 with T. reesei ATPase $\beta$ subunit gene atp2 (pTEF1-atp2-tCYC1) & This study \\
\hline pRSII326-atpAGD & $\begin{array}{l}\text { pRSIII326 with E. coli ATPase a subunit gene atpA (pTPI-atpA-tCPS1), subunit } \beta \text { gene atpD (pTEF1-atpD-tPRM9) and } \\
\text { y subunit gene atpG (pGPM1-atpG-tHIS5) }\end{array}$ & This study \\
\hline pRSII326-atpAGD (2A) & $\begin{array}{l}\text { pRSIII326 with E. coli ATPase } \alpha, \beta \text { and } \gamma \text { subunit genes atpAGD joined with viral } 2 A \text { peptide sequences under the } \\
\text { control of TEF1 promoter }\end{array}$ & This study \\
\hline
\end{tabular}

in an anaerobic chamber (don whitley scientific, United Kingdom) with an oxygen-free atmosphere composed of $10 \% \mathrm{H}_{2}, 10 \% \mathrm{CO}_{2}$ and $80 \% \mathrm{~N}_{2}$.

\section{Analytical methods}

ATPase activity of the cell lysates was measured using the ATPase Activity Assay Kit (Colorimetric) from BioVision (\#K417). Pellets were made from strains cultivated anaerobically in $10 \mathrm{~mL}$ mineral salt medium and were stored at $-80{ }^{\circ} \mathrm{C}$ until further use. Cell disruption was done via chemical lysis with CellLytic Y (Sigma) supplemented with $10 \mathrm{mM}$ DTT and EDTA-free protease inhibitor cocktail (Roche) according to the manufacturers protocol. Lysates were centrifuged at $10,000 \times g$ for $10 \mathrm{~min}$ at $4{ }^{\circ} \mathrm{C}$. Supernatants were transferred to Eppendorf tubes (or 1.5-mL reaction tubes) and further treated according to the manufacturer's protocol. The ATPase activity was normalized to the total protein content in the lysate which was determined via measuring the absorbance at $280 \mathrm{~nm}$ on a NanoDrop 1000 spectrometer (peqlab Biotechnologie $\mathrm{GmbH}$ ).

An Agilent 1100 series HPLC system equipped with a REZEX-ROA column (phenomenex, 00H-0138-K0, $300 \times 7.8 \mathrm{~mm}$ ) was used to quantify glucose, ethanol, glycerol and acetate in sample supernatants using $4 \mathrm{mM} \mathrm{H}_{2} \mathrm{SO}_{4}$ as liquid phase. Filtered samples were separated at $65{ }^{\circ} \mathrm{C}$ and $0.5 \mathrm{~mL} / \mathrm{min}$ for $35 \mathrm{~min}$ with detection using a refractive index detector. Data were analyzed using the Chromeleon (Thermo Scientific) software package.

The specific rates for growth-coupled experiments were measured using the following formula:

$$
r=\mu\left(c_{M, e}-c_{M, s}\right) /\left(c_{X, e}-c_{X, s}\right) \quad[\mathrm{mmol} / \mathrm{gCDW} / \mathrm{h}],
$$

where $\mu$ is the growth rate, $c_{M, e}$ and $c_{M, s}$ represent the end and start concentrations of the respective metabolite $\mathrm{M}$ (mmol/L glucose, ethanol, glycerol, or acetate) and $c_{X, e}$ and $c_{X, S}$ represent the end and start concentrations of the biomass $(\mathrm{gCDW} / \mathrm{L})$. In growth-decoupled experiments, the biomass concentration remained nearly constant and, therefore, the following formula was employed for calculating the specific rates:

$$
r=\left(c_{M, e}-c_{M, s}\right) / X_{\mathrm{Av}} / \Delta t \quad[\mathrm{mmol} / \mathrm{gCDW} / \mathrm{h}],
$$

where $X_{\mathrm{Av}}$ is the average biomass concentration $(\mathrm{gCDW} / \mathrm{L})$, and $\Delta t=t_{e}-t_{\mathrm{s}}$ the length of the time period (difference of end and start time).

For the volumetric productivities (in both growth-coupled and growth-decoupled cultivations), we used the formula: 


$$
q=\left(c_{M, e}-c_{M, s}\right) / \Delta t \quad[\mathrm{mmol} / \mathrm{L} / \mathrm{h}]
$$

Yields were determined by plotting the amount of synthesized product (ethanol, glycerol, acetate, biomass) against the consumed glucose for every measurement time point and computing the slope of the linear regression, which then represents the respective yield.

The respective time periods used for the calculations of rates, productivities and yields are mentioned in the text.

\section{Supplementary information}

Supplementary information accompanies this paper at https://doi. org/10.1186/s13068-020-01822-9.

Additional file 1. DNA sequence of genes and regulatory elements used in this study.

\section{Acknowledgements}

We are grateful to Ruxandra Rehner for technical assistance in metabolite quantification (HPLC).

\section{Authors' contributions}

$\mathrm{AZ}$ and $\mathrm{KM}$ conceived, designed and performed the experiments with input from all the authors. All the authors contributed to data analysis and writing of the paper. All the authors read and approved the final manuscript.

\section{Funding}

Open Access funding enabled and organized by Projekt DEAL.. This work was financially supported by the European Research Council (ERC Consolidator Grant 721176)

\section{Availability of data and materials}

The authors declare that all data supporting the findings of this study are available within the paper and its Supplementary Information files or are available from the corresponding author on request.

\section{Ethics approval and consent to participate}

Not applicable.

\section{Consent for publication}

Not applicable.

\section{Competing interests}

The authors declare that they have no competing interests.

Received: 2 March 2020 Accepted: 23 October 2020

Published online: 09 November 2020

\section{References}

1. Cherubini F. The biorefinery concept: using biomass instead of oil for producing energy and chemicals. Energy Convers Manag. 2010;51:1412-21.

2. Busic A, Mardetko N, Kundas S, Morzak G, Belskaya H, Santek MI, Komes D, Novak S, Santek B. Bioethanol production from renewable raw materials and its separation and purification: a review. Food Technol Biotech. 2018:56:289-311.

3. Favaro L, Jansen T, van Zyl WH. Exploring industrial and natural Saccharomyces cerevisiae strains for the bio-based economy from biomass: the case of bioethanol. Crit Rev Biotechnol. 2019;39:800-16.

4. Ruchala J, Kurylenko OO, Dmytruk KV, Sibirny AA. Construction of advanced producers of first- and second-generation ethanol in Saccharomyces cerevisiae and selected species of non-conventional yeasts (Scheffersomyces stipitis, Ogataea polymorpha). J Ind Microbiol Biotechnol. 2020;47:109-32.
5. Dmytruk KV, Kurylenko OO, Ruchala J, Abbas CA, Sibirny AA. Genetic improvement of conventional and nonconventional yeasts for the production of first- and second-generation ethanol. In: Sibirny AA, editor. Biotechnology of Yeasts and Filamentous Fungi. Cham: Springer International Publishing; 2017. p. 1-38.

6. Benisch F, Boles E. The bacterial Entner-Doudoroff pathway does not replace glycolysis in Saccharomyces cerevisiae due to the lack of activity of iron-sulfur cluster enzyme 6-phosphogluconate dehydratase. J Biotechnol. 2014;171:45-55.

7. Fuhrer T, Fischer E, Sauer U. Experimental identification and quantification of glucose metabolism in seven bacterial species. J Bacteriol. 2005:187:1581-90.

8. Basso TO, de Kok S, Dario M, do Espirito-Santo JCA, Muller G, Schlolg PS, Silva CP, Tonso A, Daran JM, Gombert AK, et al. Engineering topology and kinetics of sucrose metabolism in Saccharomyces cerevisiae for improved ethanol yield. Metab Eng. 2011;13:694-703.

9. Weusthuis RA, Adams H, Scheffers WA, Vandijken JP. Energetics and kinetics of maltose transport in Saccharomyces cerevisiae: a continuous culture study. Appl Environ Microbiol. 1993;59:3102-9.

10. de Kok S, Kozak BU, Pronk JT, van Maris AJ. Energy coupling in Saccharomyces cerevisiae: selected opportunities for metabolic engineering. FEMS Yeast Res. 2012;12:387-97.

11. Hädicke $\mathrm{O}$, Bettenbrock K, Klamt S. Enforced ATP futile cycling increases specific productivity and yield of anaerobic lactate production in Escherichia coli. Biotechnol Bioeng. 2015;112:2195-9.

12. Hädicke $\mathrm{O}$, Klamt S. Manipulation of the ATP pool as a tool for metabolic engineering. Biochem Soc Trans. 2015;43:1140-5.

13. Navas MA, Cerdan S, Gancedo JM. Futile cycles in Saccharomyces cerevisiae strains expressing the gluconeogenic enzymes during growth on glucose. Proc Natl Acad Sci USA. 1993;90:1290-4.

14. Semkiv MV, Dmytruk KV, Abbas CA, Sibirny AA. Activation of futile cycles as an approach to increase ethanol yield during glucose fermentation in Saccharomyces cerevisiae. Bioengineered. 2016;7:106-11.

15. Koebmann BJ, Solem C, Pedersen MB, Nilsson D, Jensen PR. Expression of genes encoding $F_{1}$-ATPase results in uncoupling of glycolysis from biomass production in Lactococcus lactis. Appl Environ Microbiol. 2002;68:4274-82

16. Koebmann BJ, Westerhoff HV, Snoep JL, Nilsson D, Jensen PR. The glycolytic flux in Escherichia coli is controlled by the demand for ATP. J Bacteriol. 2002:184:3909-16.

17. Boecker S, Zahoor A, Schramm T, Link H, Klamt S. Broadening the scope of enforced ATP wasting as a tool for metabolic engineering in Escherichia coli. Biotechnol J. 2019;14:1800438.

18. Liu J, Kandasamy V, Wurtz A, Jensen PR, Solem C. Stimulation of acetoin production in metabolically engineered Lactococcus lactis by increasing ATP demand. Appl Microbiol Biotechnol. 2016:100:9509-17.

19. Semkiv MV, Dmytruk KV, Abbas CA, Sibirny AA. Increased ethanol accumulation from glucose via reduction of ATP level in a recombinant strain of Saccharomyces cerevisiae overexpressing alkaline phosphatase. BMC Biotechnol. 2014;14:42.

20. Sibirny A, Semkiv MV, Dmytruk KV. Improvement of ethanol yield and reduction of biomass accumulation in the recombinant strain of Saccharomyces cerevisiae overexpressing ATP degrading the enzymes. 2010. WO2010151866A2

21. Jensen PR, Snoep JL, Westerhoff HV. Method of improving the production of biomass or a desired product from a cell. 1998. WO1998010089A1.

22. Saita E, Suzuki T, Kinosita K, Yoshida M. Simple mechanism whereby the $F_{1}$-ATPase motor rotates with near-perfect chemomechanical energy conversion. Proc Natl Acad Sci USA. 2015;112:9626-31.

23. Leyva JA, Bianchet MA, Amzel LM. Understanding ATP synthesis: structure and mechanism of the F1-ATPase (Review). Mol Membr Biol. 2003:20:27-33.

24. Koebmann BJ, Westerhoff HV, Snoep JL, Solem C, Pedersen MB, Nilsson D. Michelsen O, Jensen PR. The extent to which ATP demand controls the glycolytic flux depends strongly on the organism and conditions for growth. Mol Biol Rep. 2002;29:41-5.

25. Curran KA, Karim AS, Gupta A, Alper HS. Use of expression-enhancing terminators in Saccharomyces cerevisiae to increase mRNA half-life and improve gene expression control for metabolic engineering applications. Metab Eng. 2013;19:88-97. 
26. Partow S, Siewers V, Bjorn S, Nielsen J, Maury J. Characterization of different promoters for designing a new expression vector in Saccharomyces cerevisiae. Yeast. 2010;27:955-64.

27. Sun J, Shao ZY, Zhao H, Nair N, Wen F, Xu JH, Zhao HM. Cloning and characterization of a panel of constitutive promoters for applications in pathway engineering in Saccharomyces cerevisiae. Biotechnol Bioeng. 2012;109:2082-92.

28. Beekwilder J, van Rossum HM, Koopman F, Sonntag F, Buchhaupt M, Schrader J, Hall RD, Bosch D, Pronk JT, van Maris AJA, Daran JM. Polycistronic expression of a beta-carotene biosynthetic pathway in Saccharomyces cerevisiae coupled to beta-ionone production. J Biotechnol. 2014;192:383-92.

29. Geier M, Fauland P, Vogl T, Glieder A. Compact multi-enzyme pathways in P. pastoris. Chem Comm. 2015;51:1643-6.

30. Souza-Moreira TM, Navarrete C, Chen X, Zanelli CF, Valentini SR, Furlan M, Nielsen J, Krivoruchko A. Screening of 2A peptides for polycistronic gene expression in yeast. FEMS Yeast Res. 2018;18:foy036.

31. Zahoor A, Kuttner FTF, Blank LM, Ebert BE. Evaluation of pyruvate decarboxylase-negative Saccharomyces cerevisiae strains for the production of succinic acid. Eng Life Sci. 2019;19:711-20.

32. Mans R, van Rossum HM, Wijsman M, Backx A, Kuijpers NGA, van den Broek M, Daran-Lapujade P, Pronk JT, van Maris AJA, Daran JMG. CRISPR/ Cas9: a molecular Swiss army knife for simultaneous introduction of multiple genetic modifications in Saccharomyces cerevisiae. FEMS Yeast Res. 2015;15:fov004.

33. Wijsman M, Swiat MA, Marques WL, Hettinga JK, van den Broek M, Cortes PD, Mans R, Pronk JT, Daran JM, Daran-Lapujade P. A toolkit for rapid CRISPR-SpCas9 assisted construction of hexose-transport-deficient Saccharomyces cerevisiae strains. FEMS Yeast Res. 2019;19:fov107.

34. Stovicek V, Holkenbrink C, Borodina I. CRISPR/Cas system for yeast genome engineering: advances and applications. FEMS Yeast Res. 2017;17:fox030

35. Jessop-Fabre MM, Jakociunas T, Stovicek V, Dai Z, Jensen MK, Keasling JD, Borodina I. EasyClone-MarkerFree: a vector toolkit for marker-less integration of genes into Saccharomyces cerevisiae via CRISPR-Cas9. Biotechnol J. 2016;11:1110-7.

36. Chee MK, Haase SB. New and redesigned pRS plasmid shuttle vectors for genetic manipulation of Saccharomyces cerevisiae. G3 (Bethesda). 2012;2:515-26.
37. Klamt S, Mahadevan R, Hädicke O. When do two-stage processes outperform one-stage processes? Biotechnol J. 2018;13:1700539.

38. Johnston GC, Singer RA, Mcfarlane ES. Growth and cell division during nitrogen starvation of the yeast Saccharomyces cerevisiae. J Bacteriol. 1977:132:723-30.

39. Tesniere C, Brice C, Blondin B. Responses of Saccharomyces cerevisiae to nitrogen starvation in wine alcoholic fermentation. Appl Microbiol Biotechnol. 2015;99:7025-34.

40. Schulze U, Lidén G, Nielsen J, Villadsen J. Physiological effects of nitrogen starvation in an anaerobic batch culture of Saccharomyces cerevisiae. Microbiology (Reading, Engl). 1996;142:2299-310.

41. Hazelwood LA, Walsh MC, Luttik MAH, Daran-Lapujade P, Pronk JT, Daran $J$-M. Identity of the growth-limiting nutrient strongly affects storage carbohydrate accumulation in anaerobic chemostat cultures of Saccharomyces cerevisiae. Appl Environ Microbiol. 2009;75:6876-85.

42. Lan El, Liao JC. ATP drives direct photosynthetic production of 1-butanol in cyanobacteria. Proc Natl Acad Sci USA. 2012;109:6018-23.

43. Ku JT, Lan El. A balanced ATP driving force module for enhancing photosynthetic biosynthesis of 3-hydroxybutyrate from $\mathrm{CO}_{2}$. Metab Eng. 2018;46:35-42.

44. Ebert BE, Kurth F, Grund M, Blank LM, Schmid A. Response of Pseudomonas putida KT2440 to increased NADH and ATP demand. Appl Environ Microbiol. 2011;77:6597-605.

45. Pronk JT. Auxotrophic yeast strains in fundamental and applied research. Appl Environ Microbiol. 2002;68:2095-100

46. Verduyn C, Postma E, Scheffers WA, Van Dijken JP. Effect of benzoic acid on metabolic fluxes in yeasts: A continuous-culture study on the regulation of respiration and alcoholic fermentation. Yeast. 1992;8:501-17.

47. Andreasen AA, Stier TJB. Anaerobic nutrition of Saccharomyces cerevisiae. I. Ergosterol requirement for growth in a defined medium. J Cell Physiol. $1953 ; 41: 23-36$

\section{Publisher's Note}

Springer Nature remains neutral with regard to jurisdictional claims in published maps and institutional affiliations.
Ready to submit your research? Choose BMC and benefit from:

- fast, convenient online submission

- thorough peer review by experienced researchers in your field

- rapid publication on acceptance

- support for research data, including large and complex data types

- gold Open Access which fosters wider collaboration and increased citations

- maximum visibility for your research: over $100 \mathrm{M}$ website views per year

At $\mathrm{BMC}$, research is always in progress.

Learn more biomedcentral.com/submissions 